\title{
Sexual Violence against Indigenous Women: Policies, Human Rights and the Myth of Development
}

\begin{abstract}
This paper addresses issues regarding the definition of sexual violence in the context of Canada's development discourse in the Third World vis-à-vis the domestic experiences of Indigenous women. Despite the fact that sexual violence is often defined as rape or unwanted sexual contact, the author argues that Indigenous female victims of sexual violence are strongly influenced by other systems of oppression. Systems like the coloniality of power, a term coined by Anibal Quijano, the coloniality of gender, a term best explored in the works of Maria Lugones, capitalism, heteropatriarchy and racism, among others, should be considered when discussing women of colour's experiences of sexual violence. Hence, the notion of sexual violence purely as rape further marginalizes women of colour, including Indigenous women. Through the notion of intersectionality (Crenshaw 1991), this article aims to produce change towards redefining sexual violence in a way that better reflects the experiences of women of colour, while challenging systemic oppression.
\end{abstract}

KEYWORDS: Sexual violence, Indigenous women, Development, Policy, Intersectionality, Coloniality

a

Settlers are able to repress what they would rather not be reminded of - that the land is stolen - and simultaneously, if Aboriginal people are waste and if the inquest can confirm that their lives are indeed wasted lives, settlers confirm themselves as the rightful owners.

— (Razack 2011: 358)

This paper is a preliminary attempt to point out the ways in which definitions of sexual violence in Canada, particularly as they are used to develop policies and programming in developing countries ${ }^{1}$ (Escobar 1995: 5) undermine Indigenous women's experiences of sexual violence domestically. My work stems from my engagement with decolonial, Indigenous feminist and intersectional literature and 
my professional experience as a junior gender analyst at the Department of Foreign Affairs Trade and Development (DFATD).

Canada is deeply involved in the development rhetoric. The Department of Foreign Affairs, Trade and Development, which was amalgamated in 2013-2014 as "part of a natural evolution"(Fantino, Globe and Mail, March 26, 2013: n.p.) towards a model that favours Canadian economic and political interests in development work, (DFATD, “Our Priorities" 2014: n.p.) has been vehicle through which Canada has established itself as a major donor and contributor of development projects worldwide in the past years. Nonetheless, amalgamation has also brought along challenges to practitioners of development work. For instance, Canada's focus on its economic agenda has favoured the engagement of the extractive industry in developing countries under the banner of "economic development" (Mining Watch 2014: n.p.). Thus, human rights approaches, which have been traditionally used by Canada's development agency (previously known as Canadian International Development Agency-CIDA), are now being put to the services of political and economic diplomacy.

The issue of sexual violence becomes relevant in two different ways. First, through how sexual violence is defined by mainstream policy, international law and human rights approaches. Second, through Canada's international agenda on gender equality vis-à-vis the situation of Indigenous women domestically. Thus, this paper will address the issue of definition, as a preliminary approach to challenging the way in which current characterizations of sexual violence affect women of colour, particularly Indigenous women.

\section{Understanding Sexual Violence in the Policy Context}

Typically and traditionally, the state apparatus has not treated gender issues and gender crimes with an equitable and appropriate level of importance, until such time as public and political pressure induce policy and procedural change. Moreover, it is important to recognize that although policies and procedures may have altered within the institution, many of the prevailing ideologies, norms, values and beliefs continue to be produced and reproduced by practitioners within the criminal justice system.

\section{— (James F. Hodgson and Debra S. Kelley 2012: 5)}

At different points in time and place, sexual violence has been deemed to be private and not under the State's jurisdiction. Feminist groups (of various kinds) across the world have made it an issue, which has resulted in important legal gains, including rape-shields in the context of Canada (Bumiller 2008: 15). Whether it is marital rape, domestic violence, rape by strangers, date-rape, sexual harassment, verbal harassment, or murder, among others, the topic stirs important discussions in legal, policy and civil society circles. 
Although the Convention on the Elimination of All Forms of Discrimination against Women (CEDAW) covers sexual violence in different sections of the Convention (including article 1, 2, 5, 6, 11, 12 and 16) (UN Women, "CEDAW General Recommendations" n.d.), there is ambiguity in terms of what exactly constitutes "sexual violence." For instance, articles 2, 5 and 10 discuss sexual violence in the context of pornography and women's sexual objectification; article 6 refers to trafficking and rape during war; and article 11 discusses sexual harassment in the workplace (n.p.). Thus, what is sexual violence, and what exactly does it entail? Definition is a wider issue that is reflected in the policy and legal literature; in fact, sexual violence is often defined as "rape" or unwanted advances of a sexual nature. Policy and mainstream feminist literature pay little consideration to other factors that, in my view, influence Indigenous women's experience of sexual violence, such as colonialism, State violence, capitalist exploitation, land-grabbing, etc.

Sexual violence is a timely topic. Not only is Canada experiencing increasing activist mobilization due to the multiple and persistent rapes, disappearances and murders of Indigenous women across the country, but Indigenous and non-Indigenous NGOs and grassroots organizations have gotten involved in the discussion. For instance, the Canadian Network of Women's Shelters and Transition Houses (CNWSTH) believes that Canada needs a national strategy to deal with violence against women (CNWSTH 2013: 4), in general. CNWSTH acknowledges the marginalization of Indigenous women in Canada, and proposes culturally-sensitive approaches to assist abused Indigenous women (21-22). The Assembly of First Nations (AFN) agrees with the national strategy, and it has supported the Native Women's Association of Canada's (NWAC) petition for a national inquiry (Assembly of First Nations, AFN, October 12, 2012, n.p.). Yet, the AFN rejects the idea that violence against Indigenous women will stop by funding more police or increased legal interventions; instead, they advocate for community-based initiatives (AFN n.d.: 3). At the same time the Native Women's Association of Canada is calling the Canadian Government to launch an inquiry on missing and murdered Indigenous women, an effort that until now has been futile (NWAC 2014: n.p.).

Yet, this is not a uniform or homogenous process. Other organizations, such as Families of Sisters in Spirit (FSIS), a grassroots organization based in Ottawa, do not support the inquiry and have pointed out a number of issues with State-centric approaches (Indigenous Waves 2014: n.p.). A major concern for them is that they view the Canadian State as the primary perpetrator of violence against Indigenous women; thus, calling for a government-led inquiry is an oxymoron. Several policy and legal disappointments have led FSIS to believe that change has to come from Indigenous peoples, particularly women, who have experienced violence in multifaceted ways. And they are not the only ones. Last year the hashtags \#itstartswithus ("Honouring the Lives of Missing and Murdered Indigenous Women" n.d.: n.p.), \#itendshere (INW Collective 2014: n.p.) and \#Iamnotnext (The Huffington Post Canada 2014: n.p.) involved a number of Twitter followers and participants, 
who called for community engagement on the issue of violence against Indigenous women with a non-State-centric focus.

To add complexity to the issue, the recent discussions around bill C-36 (colloquially called the anti-prostitution bill) (Wingrove 2014: n.p.) has resulted in a problematic government-led consultation process, and numerous disagreements among feminists, NGOs, sex workers, and others. Being in a high-risk profession ${ }^{2}$ by choice, some sex workers (Indigenous and otherwise) have pointed out that bill C-36 violates their rights and safety, and the recommendations proposed by CNWSTH, AFN, NWAC, and other organizations fail to include them in a dignified manner, while making moral arguments to prevent sex-workers from acquiring rights and enjoying social-security provisions (KweToday 2014: n.p.).

The primary issue with how sexual violence is conceptualized in policy, the media and human rights-centric circles is that the definitions do not transcend the actual physical aspect of rape and murder. The question is, should sexual violence be understood only in this way? And if so, how does this definition impact the experiences of women of colour, particularly Indigenous women?

While using the existing definitions of sexual violence as rape and unwanted physical contact, Amnesty International's Maze of Injustice report, argues that Indigenous women are strongly affected by sexual violence (Amnesty International 2007: 2-5). In Canada, Indigenous women are five times more likely to suffer sexual violence (NWAC 2015: n.p.), while in the United States the same women are nine times more prone to be sexually attacked (Amnesty International 2007: 36). Now, it is important to also recognize that most of the data available in Canada is not necessarily current. In 2010 the Conservative Government made the traditional long-form census a "voluntary" procedure, which has strongly impacted the ability of researchers to track important trends, such as those involving violence against women (Grant, The Globe and Mail,January 29, 2015, n.p.). Statistics are favoured in policy discussions in Western countries and are used to produce legal and policy changes (Lister 2012: 2-3). Hence, the unavailability of data severely affects many communities' ability to demand change within the machinery of the State.

Jodi Beniuk argues that the State benefits from creating policy barriers, so minorities cannot access processes or resources easily (Beniuk 2012: 91). In this sense, policy has been often used to maintain the status quo, and protect the interests of particular members of political and economic elites. Such a view of public policy has led numerous groups, including Indigenous peoples around the world to be skeptical not only of the State, but of International organizations such as the United Nations (UN), the World Bank (WB) or the International Monetary Fund (IMF). In Canada, and other countries, Indigenous populations have been the subject of "regulatory techniques." These techniques are the ways in which the State implements policy (Lister 2012: 123). Ruth Lister suggests three main techniques, "classification" (medicalization of social conditions; i.e. "Indigenous peoples 
alcoholism"), "normalization" (individuals are differentiated according to desired norms; i.e. Indigenous women as squaws) and "surveillance" (gazing normalization that allows punishment; i.e. overrepresentation of Indigenous women in Canadian jails) (116-123).

What Lister suggests in terms of policy is particularly relevant to the research on violence against Indigenous women. For instance, Canada's commitment and ratification of CEDAW and the Beijing Platform are considered to be drivers of domestic policy. The problem is that if policy has been characterized by regulating minorities, such as Indigenous peoples, where do human-rights approaches (i.e. CEDAW and Beijing Platform) fit in the policy process? Is there a contradiction between protecting rights and regulating people? Or does the State "grant" rights to further regulate?

\section{Violence Beyond Policy}

"One of the most immediate questions people ask is why do Indigenous women, specifically, experience more violence? The answer is simple: it is because we are Indigenous and we are women.” -- (Tasha Beeds 2014: n.p.)

In Canada sexual violence is defined in legalistic terms that describe isolated actions (like rape or sexual harassment) often perpetrated by a man against a woman. Yet, mainstream attempts to provide more "comprehensive" approaches, often fall short because they lack a consideration of intersectionality and the experiences of women of colour. For instance, in an effort to depart from the definition of sexual violence as purely physical rape, Heberle and Grace argue that "sexual violence [...] could describe forms of molestation that do not include penetration" (Heberle and Grace, 2009: 4). The challenge with describing sexual violence as isolated events is that then we fail to make connections between rape and harassment, and the systems that enable sexual violence to thrive. Likewise, we overlook the power relations that put Indigenous women, and other women of colour, under particular risk of suffering sexual violence.

In the recent blog series \#Itendshere honouring Loretta Saunders, an Inuit woman and PhD student at Saint Mary's University who was brutally murdered at the beginning of 2014, the authors connect sexual violence and murder of Indigenous women to a broader picture of colonial violence. Leanne Simpson, one of the contributors explains, "Gender violence and murdered and missing Indigenous women are a symptom of settler colonialism, white supremacy and genocide. They are symptoms of the dispossession of Indigenous peoples from our territories" (Simpson 2014: n.d.). Literature from across disciplines shows that the sphere of public policy has failed to encompass the multifaceted oppressions that Indigenous women experience not only in Canada, but across the world. Today, saying that violence against Indigenous women happens because of their womanhood and 
their Indigeneity, requires further analysis of how gender, sexuality and Indigeneity intersect with colonial violence and epistemic, social and economic marginalization.

In engaging with decolonial, Indigenous feminist and intersectional literature, I have identified five essential areas that, if considered as part of women's experiences of sexual violence, would challenge the way policy circles deal with the matter. These areas are not all encompassing or exhaustive; instead, they represent an attempt to engage in rethinking power relations and their impact on sexual violence against Indigenous women.

\section{Colonialism, Race and Coloniality}

The key aspect of these relationships is the connections between colonialism and racism as systems that sustain the coloniality of power. Anibal Quijano sees colonization as a process through which the idea of "race" became the basis of social organization (Quijano and Ennis 2000: 534). "Race" did not only serve the political purposes of social classification and hierarchization (534), but it further served capitalism as a way to distribute labour and exploit Indigenous resources (536-537).

What is more, colonialism and the idea of "race" would shape the colonizer and the colonized even centuries after initial contact . Racial hierarchization, according to Quijano, also supported racial, political, economic and epistemic Eurocentrism (541). Eurocentrism, as a doctrine that preaches biological/natural racial differentiation, the superiority of the male-white-Western-European and a notion of linear "development" towards modernity (542), has influenced not only the State apparatuses and development discourses (one has only to look at the literature offered by Modernization theorists like W.W. Rostow ${ }^{3}$ and Samuel Huntington ${ }^{4}$ ), but also those who were colonized.

One of the main contributions that Quijano have to offer to the theorization on the oppression of Indigenous women, is the idea of coloniality. Coloniality goes beyond the racial classification and imposes power relations around every aspect of a colonized person's life including authority, sexuality, labour, epistemology, etc. (Lugones 2008: 3). The key difference between colonialism and coloniality is that colonialism in itself does not include power relations based on race, these are developed through coloniality (3). Walter Mignolo suggests that the power of coloniality lays in how colonized peoples conceive themselves according to the categories created and imposed by the colonizer (Mignolo "Geopolitics of Sensing and Knowing" 2011: 8). In fact, in his work Quijano identifies four realms that represent the "pattern of coloniality of power;" these are the economy and labour, authority, gender and sexuality and epistemology and the creation of knowledge (8). Epistemologically speaking coloniality expresses itself in diverse ways; for instance, through the notion of "the Indian" as inferior, without past, without knowledge and as a dependent of the colonizer. Coloniality makes Indigenous populations vulnerable by subjecting them to racial, sexual, economic and political violence, while suppressing their 
pre-colonial identity and forcing them into Eurocentric categories, which continue to be reproduced (Maldonado-Torres 2007: 247).

María Lugones takes the concept further and shows the extent to which coloniality makes women of colour invisible. In her analysis, Lugones proposes that it is important to understand women of colour in three main ways. First, gender and biological sex, just like "race," are inventions of the colonial imagination (Lugones 2010: 6). Next, patriarchy is not a "natural" and "universal" category (8). Finally, failure to acknowledge how race and gender are fused, lead us to the faulty assumption that women of colour do not exist or that their oppressions are those of privileged, white women (4).

\section{Sex, Heteronormativity and Gender}

Sex and gender are closely interrelated with colonial definitions of race. In fact, numerous reports quote the intersection of sex, gender and race as the primary reason why Indigenous women suffer more violence than other women around the world (Amnesty International 2007:15-16; NWAC 2015: n.p.). Lugones' point about gender and sex as fictional categories is something that has been picked up by other authors, particularly in view of the third gender. In this regard, Lugones argues, "[the term] does not mean that there are three genders. It is rather a way of breaking the sex and gender bipolarity. The 'third' gender is emblematic of other possible combinations...”(Lugones 2010:11). In many societies around the world, including those permeated by colonialism, it can be very hard to conceive the idea of a 'third' gender because we have been epistemologically and socially conditioned through education, religion and social norms to see the world through colonial binaries. However, Deborah Miranda presents us with the story of "Las Joyas" (men who dressed and worked as women) and their extermination in California, to show how sex, heteronormativity and gender continue to be a source of physical, political and epistemological domination in today's societies and Indigenous communities (Miranda 2010).

The extermination of Indigenous groups in California was not only a brutal process of genocide, but also encompassed gendercide. Miranda defines gendercide as “.... an attack on a group of victims based on the victims' gender/sex" (258). In California, the Spaniards exercised gendercide against primarily, although probably not exclusively, against "Las Joyas" (265). Originally called 'aqi' within their communities, Miranda argues that the name "Joyas" probably derived from the Spanish word "Jotos" (faggots) (267). "Las Joyas" were not only revered members of their communities because of their sexual power, but also their spiritual one. In fact, Miranda locates them as the primary caretakers of death rituals $(269,276)$. The gendercide of "Las Joyas" did not only make Indigenous communities spiritually vulnerable, but also forced them into heteronormativity (267). Thus, Miranda argues that it is possible that one of the reasons why some Indigenous communities adopted 
homophobic behaviours that did not exist before colonization was for their own survival (267).

The ways in which Indigenous women are oppressed through heteronormativity, biological ideas of sex and binaries of gender, cannot be separated from the process of colonization and the ways in which coloniality is expressed. In fact, Sueli Carreiro suggests that how these processes intersect is the source of sexual violence against women of colour (Carneiro 2005: 21-22). This is relevant because violence against women of colour and Indigenous women, is often categorized in terms of their heterosexuality and their relation to Western archetypes of womanhood and femininity.

\section{Neoliberal Capitalism, Globalization and the State}

Policy circles, international bodies such as the UN and human rights organizations like Amnesty International and Human Rights Watch have identified poverty as one of the main drivers of violence against women in the so-called Third World ${ }^{5}$. Consequently, several organizations talk about development and the eradication of gender-based violence as a matter of access to economic resources. By economic resources, though, they often mean access to the capitalist market. For instance, DFATD is currently championing Women's Economic Empowerment programming through women's vocational training, access to markets, private property and credit (DFATD, "Women's Economic Empowerment: Guidance Note" 2014: n.p.). DFATD programming targeted towards women may include work with Indigenous women and other minorities in the Third World; thus, what is wrong with such development ideas? Why are they problematic?

Both policy and development frameworks tend to be uncritical of neoliberal capitalism and the role of the state in perpetuating inequalities, pushing for assimilation and encouraging the dispensability of Indigenous women's bodies. This also comes along with an unwillingness to challenge the very processes that colonization has endorsed, not to mention a resistance to acknowledge that colonialism is still an issue that permeates the Indigenous experience.

Today, mainstream policy-makers and development officers deem capitalism as the de facto and unquestionable economic system. Yet, relevant questions such as, what are the systems that feed into neoliberal capitalist policies? And how do they interact with women of colour? are often overlooked in policy discourses, particularly in those that endorse the liberalization of economic systems for the purposes of development in Third World countries, such as those coming from the WB and the IMF (Escobar 1995: 176). Unfortunately, an in-depth discussion of the capitalist system is beyond the scope of this paper, but it is important to mention that these systems of oppression work with the State and ultimately affect Indigenous women's experiences of violence. 
Wendy Brown defines neoliberalism as "a normative and constructive project in that involves developing institutional discourses and practices that produce market as the central plank organizing all dimensions of human life" (Quoted in Dempsey, Gould and Soundberg 2011: 239). Neoliberal capitalism is a racialized process of domination that goes hand in hand with colonization; but it is also a process that incorporates "often contradictory effects and practices"(Altamirano-Jiménez 2013: 69). Quijano explains that as race became a social stratification tool of the colonial regimes, capitalism was strengthened, maintained and normalized (Quijano and Ennis 2000: 536-537). White colonizers, and in countries like Mexico mestizo populations, have benefited from the unpaid labour of Indigenous peoples and black slaves (537). The so-called "economic development" of the West came at the expense of the dispensability of bodies of colour, many of which were women (539). This system of exploitation although colonial continues to permeate racial labour stratification in some countries (540).

Resources are key to an accurate picture of how neoliberal capitalism continues to place Indigenous women in a position of dispensability and vulnerability. In discussing the criminal system and how Aboriginal peoples are mistreated by police forces in Canada, Sherene Razack describes that the violence lived by Indigenous communities results from a long-lasting fight over land and resources (Razack 2011: 356). For the purpose of appropriation, settler colonialism in Canada has made Indigenous populations into "unable beings," who cannot take care of themselves and cannot have stewardship over the land or its resources (353).

Nonetheless, neoliberal capitalism extracts from Indigenous women more than just resources. Kuokkannen points out that Indigenous women, the primary members of the subsistence sector, are the most affected group by neoliberal policies that liberalize trade and that endorse corporatism (Kuokkannen 2008: 216-217). In her analysis she describes capitalism as a process that seeks capital accumulation at all costs and that relies on patriarchies and racism to reproduce itself (221). Kuokkannen explains,

Male violence is not just analogous to the force of the state: it is part of the state, authorized by the state [...] Patriarchy is linked to force, which in turn is linked to the state. The state is not only patriarchal and colonial, but also deeply implicated in capitalist and more recently, neo-liberal ideologies.

In addition to the division of labour identified by Quijano, Kuokkannen sees globalization as an all-encompassing process that goes after Indigenous land, undermines self-determination and appropriates Indigenous knowledge (217). Thus, the processes of capitalism and globalization are closely interrelated to the areas explained above, and feed each other to create a web of conditions that prevent Indigenous women from being safe from different types of violence, including sexual, physical and economic. 
A very basic, but often forgotten, aspect of neoliberal capitalist violence is the devaluation and racialization of women's work (Méndez-Torrez 2009: 64). It is not surprising then that Indigenous women face violence as a result not only of their identity as women and as Indigenous, but also as poor (Cuminao-Rojo 2009: 113). Mignolo contributes to this discussion through the concept of "dispensable bodies." In here, he goes back to Quijano's notion of racialized division of labour to argue that the reproduction of this racialization feeds capital accumulation (Mignolo 2009: 76). Such need for resources and production deems some lives more worthy than others. Andrea Smith further speaks about this idea by explaining that among non-Indigenous societies there is an "... ideology of Native women's bodies as rapable...” (Smith 2005:30). In fact, Smith makes a strong link between Canada, the U.S. and Mexico in calling out the number of missing and murdered Indigenous women and pointing out that, despite their distinct colonial histories, the shared experiences of Indigenous women in these countries speak to common elements in how violence against them is perpetrated (30). An important observation raised by Mignolo is that 'poverty' has been defined through the lenses of modernity and capitalism; the poor, are those at the bottom of the racial scale, who are, in reality, dispensable. The capitalist system makes use of the 'poor' to justify further accumulation, and the State views them as the recipients of well-intended development (Mignolo 2009:76).

Neoliberal capitalism has not survived alone. Instead, the support of the State apparatus has been basic for its reproduction. Isabel Altamirano-Jiménez challenges the traditional economic argument about the natural survival of neoliberalism by pointing out that, "neoliberalism is not driven by an external, invisible hand, but by specific actors, sites, institutions, networks, the State, and discourses all of which have material effects in different places" (Altamirano-Jiménez 2013: 70). For instance, resource appropriation in the early years of the capitalist system during colonization was supported through policies and procedures that facilitated the removal of Indigenous bodies. Chandra Talpade Mohanty therefore speaks about an alliance between capitalism and the State, through the concept of the neoliberal State (Mohanty 2013 : 970). The neoliberal State advertises its benefits to all of us, such as mobility and communications, but these services are not widely available to everyone and are often possible through the further marginalization of the poor, which often times happens through State-led policy processes (970). Whereas Mohanty provides a general overview of the ways in which the neoliberal State exploits and oppresses people, Kuokkannen cites violence and assimilation as two of the major tools provided by the state to the neoliberal capitalist system (Kuokkannen 2008: 218), in which violence committed against Indigenous women is executed through the patriarchal systems that are part of the State (223).

The unsettling part of the neoliberal project is that it is ingrained in the machinery of the state, and it permeates the very processes that aim to "improve" or "change" the conditions of Indigenous women. Blackwell, Bumiller, Altamirano-Jiménez and 
Mohanty address the core of the issue. First, neoliberalism is seen as a "friend" to human rights, gender equality and cultural rights. The relationship is sold as that of a natural process of capitalist-neoliberal-democratic-governmentality (Blackwell 2012: 704). Next, neoliberalism has co-opted resistance. Mohanty speaks to the "domestication" of those movements that aim to negotiate, change or resist the State, such as different forms of feminisms and anti-racism movements (Mohanty 2013: 971). Bumiller further addresses how mainstream White-feminism sought to engage the state to tackle sexual violence (Bumiller 2008: 15).

Nonetheless, aside from all the oppressions that this kind of feminism has perpetuated (which will be discussed later), some movements decided to enter a "partnership" with the state to secure criminal prosecution and rape-shield policies. However, Bumiller explains, “...the feminist alliance with the state has produced something far more significant than unintended consequences-a joining of forces with a neoliberal project of social control" (15). In terms of Indigeneity, AltamiranoJiménez points out that the articulation of Indigenous rights as "cultural" rights does not challenge neoliberalism; instead, it creates a dynamic of management, where neoliberalism and the state create a highly-contained space for displays of culture, and redefine Indigenous people's identity, sense of place and articulations of rights (Altamirano-Jiménez 2013: 70-72).

\section{Epistemology, Knowledge and Sense of Being}

The ways in which colonialism, capitalism and the neoliberal State intersect have reshaped (and often undermined) Indigenous epistemologies and ontologies. The two areas are what Quijano describes as the coloniality of being and coloniality of knowledge (Mignolo “The Darker Side of Western Modernity” 2011: 8). In regards to the coloniality of being, Maldonado-Torres argues that its impact was far-reaching in how the colonized came to understand themselves and their notions of "being" (Maldonado-Torres 2007: 242). This is better articulated by Emma Chirix, who explores the concept of "subjectivity," by analyzing how Mayan women reproduce racialized attitudes that were imposed by the colonizer, but that have become widely spread in their communities (Chirix 2004: 19). Chirix argues that racist and sexist attitudes towards Indigenous women are a product of colonial relations, but they have become strongly ingrained in some Indigenous communities, who have adopted such views. The author further argues that racism is not innate; it is rather a complex process of education and reproduction of stereotypes and the dismissal of non-Indigenous values (22). The problem is that oppressions are internalized, and as Chirix mentions, once discrimination is assumed, Indigenous women tend to think they deserve violence (23).

Kim Anderson shares this experience and demonstrates that ontologies of Indigeneity were transformed through a series of forceful stereotypes that have marked many Indigenous women for life. Anderson describes two very popular colonial stereotypes in Canada. First, there is that of the "Indian princess," which holds an 
erotic appeal and is welcoming and friendly to the colonizer (Anderson 2000:101). Its antithesis is represented by that of the "easy squaw," an imagery that has deemed Indigenous women as rape-deserving (104).

Both Chirix and Anderson make straight-forward connections between the coloniality of being and sexual violence against Indigenous women. Non-Indigenous communities have also learned to see Indigenous women according to the stereotypes, which increases the likelihood of people exercising some kind of violence against those who are categorized as dispensable. Thus, Anderson argues that those women who seek justice, through formal channels, for the violence they have experienced are repeatedly deemed unworthy of such a right (110).

In terms of the coloniality of knowledge, Aileen Moreton-Robinson presents her personal experience as an Indigenous woman and as an academic to demonstrate how colonial Eurocentrism works. In describing how some white-male-privileged academics disregard Indigenous women's work, she argues that within the academy patriarchal whiteness has declared itself as the ultimate and universal source of knowledge (Moreton-Robinson 2011: 414). The attitude that she observes displayed in the academy, nonetheless, is present in different social structures, and, as she notes, has prevented Indigenous women from acquiring any kind of power (419). This, in itself, is epistemic violence.

Epistemic violence is prevalent in colonial societies, and it deems Indigenous women untrustworthy and unable to tell their own stories or act as agents. One of the latest examples is presented by Dempsey, Gould and Sundberg who describe the Canadian Conservative Government's approach to the development of Indigenous peoples. Government advisors Flanagan and Alcántara have suggested that Indigenous lands in Canada are not properly managed, which is a detriment to the economic development not only of the communities, but also of Canada as a whole (Dempsey et al.2011:235). Flanagan and Alcántara make use of epistemic violence by implying that white-Western-privilege has the answers to land "mismanagement" and by treating neoliberal development arguments as "common sense," which is said to be lacking among Indigenous leadership (248). Despite the fact that it is seemingly a practice perpetuated only by the Conservative Government, the reality of things is that different parties have engaged in similar assimilationist policies and have infantilized Indigenous communities when it comes to economic policy. Arguably, the difference is that other parties have been less blunt about it.

On a more personal level, women of colour regularly experience epistemic violence. Jennifer Jagire calls for the decolonization of feminist movements, through the "recovery" of African knowledge (Jagire 2013: 77-79). Jagire suggests that Indigenous knowledge systems have been subjugated, oppressed and neglected, but they have also been abused and appropriated by the colonizers (81). These processes happen in various ways. For instance, the conceptualization and theorization of Indigenous issues from non-Indigenous perspectives, as Velasquez Nimatuj describes, is 
a common practice among academics (Velasquez Nimatuj 2012: II). Further, these same elitist circles prevent Indigenous communities from learning what is being written about them (without them) and from using the same (or different) epistemic tools to seek different results (II). Beniuk further points out that the so-called "universal scientific knowledge" is an affront to Indigenous epistemologies because it neglects, mocks and undermines other ways of knowing and the experiences of those who have been colonized (Beniuk 2012:91).

In terms of sexual violence, epistemic violence is relevant because it encompasses a notion of having agency to be recognized and to have the power to tell one's own story. Epistemic violence has left many Indigenous communities with the idea that Indigenous peoples have no past and no sources of knowledge. Consequently, there may be a sense of not having agency to tackle their own problems and resist oppression and violence. Further, as Egla Martínez-Salazar explains, epistemic violence is expressed in the very discourses that rule Indigenous lives. The use of language and symbols are powerful ways to convey violence, and their use provides a window of opportunity to perpetuate violence against Indigenous women with impunity (Martínez-Salazar 2012: 2010).

\section{The Oppressions of Patriarchy(ies), Feminism(s) and Anti-Racist Movements}

Finally, a common theme in the literature is that of patriarchies, feminisms and anti-racism movements. While mainstream white-Western feminism has constantly blamed the oppression of women on patriarchy, defining what patriarchy is and whether or not it affects all women equally has been a challenge (Rosbech 2013: n.p.). Edwards, for instance, defines patriarchy as a "sex/gender order" that makes use of several systems and tools to control women (cited in Sweetman 1998: 3). However, several authors associate this definition with mainstream white feminisms, which are the struggle of white, heterosexual, privileged women against the structures created by white, heterosexual, privileged men (Hernández Castillo 2012: 15; Bastian Duarte 2012: 153; Carneiro 2005: 22; Oullette 2015: 15). Thus, some of the definitions of patriarchy neglect to accurately describe how women of colour experience 'the rule of men,' (Rosbech 2013: n.p) in between white supremacy, colonialism and heteronormativity. Raising questions about patriarchies is essential to discussions of sexual violence against Indigenous women because although some authors attribute the perpetuation of violence to physical advances made by men (Heberle and Grace 2009: 113), this violence has to be recognized as a symptom of a broader net of violence(s) perpetrated against Indigenous women. Thus, the questions become, how do patriarchies oppress Indigenous women (much of which was explored in other sections)? And how are Indigenous women oppressed by other movements?

Kimberle Crenshaw, often credited with one of the most important theorizations of intersectionality, highlights the difficulties of fully understanding the oppressions of women of colour through the lens of mainstream white-Western feminism and 
anti-racist movements. She argues that both movements have suppressed minority experiences in order to highlight one type of struggle (Crenshaw Williams 1991: 1991, 1252, 1258). For her, neither group could see how the intersections of race, gender and sex made the experience of women of colour radically different from that of men of colour or white women (1262). In fact, Cuminao Rojo points out that the difficulties experienced with white-Western mainstream feminists has resulted in resistance among Mapuche women to identify as feminists (Cuminao Rojo 2009: 111). Mapuche women have been largely marginalized in mainstream feminist movements, and have also found that these circles prioritize individual rights over collective rights. Such an approach forces them to neglect one part of their identity, which is an affront to their Indigeneity (Cuminao Rojo 2009: 122).

In view of the challenges that indigenous women have faced with mainstream feminist movements, Indigenous feminism has emerged as a form of resistance. Aída Hernández Castillo sees Indigenous feminism as a space, which encourages individuals to join a community of solidarity without neglecting their identities (Hernández Castillo 2010: 539). Angela Ixkic Bastián Duarte points out that Indigenous feminism challenges mainstream feminism in two important ways. First, it is skeptical of notions of "liberal individuality" adopted by mainstream feminism. Next, it questions liberal notions of "equality," which many Indigenous women have categorized as irrelevant, or simply wrong (Bastián Duarte 2012: 154, 161).

Even so, mainstream feminist movements are not the only source of oppression for Indigenous women. The complex layers of identity often held by Indigenous women can make them a target of patriarchal violence not only from white-Western apparatuses, but also within their own communities. Martha Sánchez Nestor writes that Indigenous women movements in Mexico have been accused of dividing the broader movement in favour of the rights of Indigenous women. Sánchez Nestor argues that Indigenous women movements do not want to crush the collective fight of their communities; instead, they want to make sure that the resistance is strengthened by guaranteeing the rights of Indigenous women within and outside broader movements (Sánchez Nestor 2005: 52). Méndez-Torres further acknowledges that within Indigenous grassroots movements, Indigenous women have to continuously re-negotiate their place and leadership (Méndez-Torres 2009: 24). These encounters with feminist and anti-racism movements not only present challenges to Indigenous women and other women of colour in the construction of their identity, but they continue to perpetuate their oppression and violence against them by constraining support and spaces for resistance.

\section{Redefining Sexual Violence and Going Forward}

"Rights are radical tools for those who have never had them."-- (Kapur 2006: 682) 
Taking into account the above areas of influence, and in the spirit of recognizing that the experiences of Indigenous women are intersectional and deeply marked by colonialism, I have defined sexual violence in the following manner: Sexual violence is a symptom of how different systems of oppression collide and result in the rape and harassment of Indigenous women. Indigenous women live this type of violence as a by-product of historical and contemporary colonial relations. Hence, their experiences are often "boxed" into the moral and epistemic categories of Eurocentric understandings of sex, gender and heteronomativity. Likewise, sexual violence is an indicator of how capitalism, neoliberalism and globalization have continuously taken over Indigenous women's lands, bodies and labour by making them "dispensable" and "rapable" with the State's blessing. Further, sexual violence is the result of epistemic violence perpetrated by those who reject or/and appropriate the collective knowledge systems that Indigenous peoples have developed over millennia, making them, in this way, subjects of development. Finally, sexual violence is not only the result of patriarchal oppression(s), but it is also a consequence of the failure of feminists and anti-racist movements to find grounds for solidarity and resistance.

Although this definition focuses on Indigenous women, it could pertain to the experiences of other women of colour. Further, this exercise is important for future work to reflect not only on sexual violence, but on how we think about policy and human rights approaches in general. Policy is an important vehicle of values, assumptions, implicit theories and interests that flow from the different parts of the State (Pal 2011: 1-44). Much of the policy work done traditionally in Western countries, and those relying on the colonial model of statehood and governance, has served powerful interests. For instance, Hodgson and Kelley, acknowledge that law and policy spheres are an expression of white-male-middle-class-Christian privilege in Canada (Hodgson and Kelley 2012: 3-4).

Similarly, to critique human rights in today's neoliberal environment, where they have been incorporated into the neoliberal rhetoric (Blackwell 2012: 704), is often considered to be some sort of liberal blasphemy. Nonetheless, there is no agreement, neither among scholars nor among Indigenous activists, regarding the role of human rights discourses in resistance and liberation movements. For example, Georgina Sánchez-Ramirez argues that Indigenous women have used human rights and women's rights discourses to break away from gender-based violence (Sánchez-Ramirez 2011: n.p.). Likewise, she deems human rights discourses the source of political opportunities for Indigenous women (n.p.).

But these views do not go without criticisms. Ratna Kapur sustains that the notion of human rights is strongly flawed in a very important way: human rights violations are perpetrated in the name of these rights (Kapur 2006: 665). Further, Corntassel and Bryce suggest that rights discourses are closely tied to the State, and do not reflect the needs of Indigenous communities, and their commitments to their lands (Corntassel and Bryce 2012: 152). The authors also support the view that the 
notion of rights is too conditional on the State's willingness to give, protect and honour those rights (152).

So are human rights approaches relevant or useful? In this paper I am not trying to make an argument against human rights per se. However, one cannot simply say that the right to life, to recognition before the law, to gender equality and others, is wrong. More importantly, Kapur clearly explains that despite the challenges, the human rights language is powerful in illustrating that the rhetoric is available to those who have never had rights (Kapur 2006: 682). Thus exercises, like the one presented in this paper, allow scholars to critically engage with concepts while challenging mainstream notions of policy and human rights. This work is needed in view that the numbers of women of colour exposed to sexual violence, as defined in this paper, continues to grow despite laws and conventions that assert their rights. Hence, a shift in the paradigm is needed.

To conclude, this paper has both laid the groundwork to further advance the study of sexual violence within the sphere of policy, and has developed as part of a broader research project focusing on sexual violence as a discourse of development, where the experiences of Indigenous women represent the oxymoron of Canada's development agenda. This article has focused specifically on the issue of definition because, as mentioned throughout the paper, the current legal and policy definition of sexual violence as purely rape does not reflect the experiences of women of colour, particularly of Indigenous women. The main argument presented here is that Indigenous women experience sexual violence not only physically and emotionally, but also systemically, through a net of intersecting systems that deems them dispensable. In presenting a more comprehensive understanding of sexual violence, I seek to better capture the experience of Indigenous women, who, in Canada and around the world, continue to be subjects of violence, policy and development.

\section{Notes}

1. Countries defined as "poor" since the mid 1940's.

2. "High Risk" defined as prone to violence from customers, diseases, and other factors. This is not a "moral" qualification. Work with people and the public often includes an element of risk.

3.W.W. Rostow's notion of development relied on the idea of linear economic growth. Rostow divided development into five stages that, according to him, should be followed sequentially for a society to achieve development. Societies, according to his theory, start as "Traditional Societies;" then evolve into a stage where they acquire the "Preconditions for Take-off;" next, they experience "Take-off;" later, they engage in the "Drive to Maturity" process; and finally they achieve the "Age of High Mass-Consumption."The later stages represent "modernization" for Rostow, and only a few Western countries could be counted among the "Modern" states (Rostow 1956: 25-26).

4. Samuel Huntington's views on development and economic growth are intrinsically connected to his views on civilizations. He defined civilizations as "cultural entities" and 
identified seven or eight primary civilizations: Western, Confucian, Japanese, Islamic, Hindu, Slavic-Orthodox, Latin American and "possibly" an African one. Religion is the element that sets these "civilizations" apart. Huntington sees religion also as the glue that holds economic cooperation together. The Western society is defined as the most powerful and economically established with no rivals, only imitators or antagonists (Huntington 1993: 25-43).

5. I use the term Third World, rather than the preferred "developing world," in a political way to signify that making the name sound "politically correct" does not change the realities on these countries such as their colonial histories and experiences of imperialism.

\section{References}

Altamirano-Jiménez, Isabel. 2013. Indigenous Encounters with Neoliberalism. Place, Women and the Environment in Canada and Mexico. Victoria: UBC Press.

Amnesty International. 2007. Maze of Injustice Report: The failure to protect Indigenous women from sexual violence. 1-100. http://www.amnestyusa.org/pdfs/MazeOfInjustice.pdf

Anderson, Kim. 2000. A Recognition of Being: Reconstructing Native Womanhood. Toronto: Sumach/Canadian Scholars' Press.

Assembly of First Nations. n.d. Demanding Justice and Fulfilling Rights: a Strategy to End Violence Against Indigenous Women and Girls (Draft for Full Discussion). Web. http://www. afn.ca/uploads/files/misssing_and_murdered_indigenous_women/afn_draft_strategy_to_ ensure_rights_of_indigenous_women_\&_girls_e.pdf.

Assembly of First Nations. 2012. Assembly of First Nations National Chief Reiterates Need for National Public Commission of Inquiry on Ending Violence Against Indigenous Women and Girls. Web. October 18. http://www.afn.ca/index.php/en/news-media/latest-news/ assembly-of-first-nations-national-chief-reiterates-need-for-national-

Bastian Duarte, Angela Ixkic. 2012. Full access from the margins of Latin American feminism: Indigenous and lesbian feminisms. Signs: Journal of Women in Culture and Society 38(1): 153-178.

Beeds, Tasha. 2014. In the Spirit of our Ancestors, \#Itendswithus, 11 March.Web. http:// nationsrising.org/in-the-spirit-of-our-ancestors/

Beniuk, Jodie. 2012. Indigenous Women as the Other: An Analysis of the Missing Women's Commission of Inquiring. The Arbutus Review 3(2): 80-97.

Blackwell, M. 2012. The practice of autonomy in the age of neoliberalism: Strategies from indigenous women's organising in Mexico. Journal of Latin American Studies 44(4): 703-732.

Bumiller, Kristin. 2008. In An Abusive State: How Neoliberalism Appropriated the Feminist Movement Against Sexual Violence. Durham and London: Duke University Press.

Carneiro, Sueli. 2005. Ennegrecer al feminismo. La Situacion de la mujer Negra en America Latina desde una perspectiva de Genero. Feminismos Disidentes en America Latina y el Caribe. 21-26.

Chirix, Emma. 2004. Subjetividad y racismo: la mirada de los otros y sus efectos. Los Desafios de la Diversidad-Relaciones Interetnicas: Identidad, Genero y Justicia: 19-30. 
CNWSTH. 2013. The Case for a National Action Plan on VAW. http://endvaw.ca/sites/ default/files/the_case_for_a_national_action_plan_on_vaw.pdf

Corntassel, Jeff and Cheryl Bryce. 2012. Practicing sustainable self-determination: Indigenous approaches to cultural restoration and revitalization. The Brown Journal of World Affairs 18(2): 151-162.

Crenshaw, Kimberle. 1991. Mapping the Margins: Intersectionality, Identity Politics, and Violence against Women of Colour. Stanford Law Review 43(6): 1241-1299.

Cuminao-Rojo, Clorinda. 2009. Mujeres Mapuche: voces y escritura de un posible feminismo. In Participacion y Politicas de Mujeres Indigenas en Contextos Latinoamericanos recientes, edited by Andrea Pequeño, 111-124. Ecuador: Flacso.

Dempsey, J., K. Gould and Juanita Soundberg. 2011. Changing Land Tenure, Defining Subjects. Neoliberalism and Property Regimes on Native Reserves. In Rethinking the Great White North: Race, Nature, and the Historical Geographies of Whiteness in Canada, edited by Andrew Baldwin, Laura Cameron and Audrey Kobayashi, 233-258. Vancouver: UBC Press.

Department of Foreign Affairs, Trade and Development. 2014. Our Priorities. http:// www.international.gc.ca/department-ministere/priorities-priorites.aspx?lang=eng

Department of Foreign Affairs, Trade and Development. 2014. Women's Economic Empowerment: Guidance Note. http://www.international.gc.ca/developmentdeveloppement/priorities-priorites/weegn-aefno.aspx?lang=eng

Fantino, Julian. 2013. Why CIDA Menger with Foreign Affairs, Globe and Mail, March 26. http://www.theglobeandmail.com/news/politics/ julian-fantino-why-cida-merged-with-foreign-affairs/article10343567/

Grant, Travia. 2015. Damage from cancelled census as bad as feared, researchers say, The Globe and Mail, 29 January. http://www.theglobeandmail.com/news/politics/ cities-footing-the-bill-for-data-gap-after-long-form-census-scrapped/article22695286/

Heberle, Renée J. and Victoria Grace, eds., 2009. Theorizing Sexual Violence. New York: Routledge.

Hernández Castillo, Aida. 2010. The emergence of indigenous feminism in Latin America. Signs: Journal of Women in Culture and Society 35(3): 39-59.

Hodgson, J.F. and Debra S. Kelley, eds. 2012. Sexual Violence: Policies, Practices, and Challenges in the United States and Canada. Westport, Connecticut, London: Praeger.

Honouring the Lives of Missing and Murdered Indigenous Women. n.d. http://www. itstartswithus-mmiw.com/

I'm Not Next Responds To Am I Next? Reiterates Inquiry Call. 2014. The Huffington Post, 16 September. http://www.huffingtonpost.ca/2014/09/16/im-not-next-missingmurdered-inquiry_n_5830830.html

Indigenous Waves. Colleen Cardinal from Families of Sisters in Spirit on MMIW, the problems of a National Inquiry and Colonial Violence against Indigenous Women. Podcast. Canada. 2014. http://indigenouswaves.com/2014/03/28/colleen-cardinal-from-familiesof-sisters-in-spirit-on-mmiw-the-problems-of-a-national-inquiry-and-colonial-violenceagainst-indigenous-women/

INW Collective. 2014. \#itendshere: The Full Series. Nation Rising. Retrieved from http:// nationsrising.org/itendshere-the-full-series/ 
Jagire, Jennifer. 2013. Indigenous African Knowledges and African Feminism: Resisting Eurocentric Ways of Knowing. In Ruptures: Anti-colonial \&' Anti-racist Feminist

Theorizing, edited by Njoki Wane, Jennifer Jagire and Zahra Murad, 77-90. Rotterdam/ Boston/Taipei: Sense Publishers.

Kapur, Ratna. 2006. Human Rights in the 21st Century: Take a Walk on the Dark Side. Sydney Law Review 28 (1): 665-687.

Kuokkannen, Raunna. 2008. Globalization as Racialized Violence: The Case of Indigenous Women. International Feminist Journal of Politics 10(2): 216-233.

Lister, Ruth. 2012. Understanding theories and concepts in social policy. Portland or Briston: Policy Press.

Lugones, Maria. 2008. The Coloniality of Gender. Worlds and Knowledges Otherwise: 1-17. https://globalstudies.trinity.duke.edu/wp-content/themes/cgsh/materials/WKO/ v2d2_Lugones.pdf

Lugones, Maria. 2010. Towards a Decolonial Feminism. Hypatia 25(4). 742-759.

Maldonado-Torres, Nelson. 2007. On the Coloniality of Being. Contributions to the Development of a Concept. Cultural Studies 21(2): 240-270.

Martinez-Salazar, Egla. 2012. Global Coloniality of Power in Guatemala. Racism, Genocide, Citizenship. Baltimore: Lexington Books.

Méndez-Torrez, Georgina. 2009. Miradas de Género de las mujeres indígenas en Ecuador, Colombia y Mexico. In Participacion y Politicas de Mujeres Indigenas en Contextos Latinoamericanos recientes, edited by Andrea Pequeño, 53-72. Ecuador: Flacso.

Mignolo, Walter. 2009. Dispensable and Bare Lives: Coloniality and the Hidden Political/Economic Agenda of Modernity. Human Architecture: Journal of the Sociology of Self-Knowledge VII (2): 69-88.

Mignolo, Walter. 2011. Geopolitics of Sensing and Knowing. On Transversal (De) Coloniality, Border Thinking, and Epistemic Disobedience. Postcolonial Studies 14(3).

Mignolo, Walter. 2011. The Darker Side of Western Modernity. Durham: Duke University Press.

Mining Watch. 2014. Brief: The Canadian International Institute for Extractive Industries and Development (CIIEID). http://www.miningwatch.ca/article/ brief-canadian-international-institute-extractive-industries-and-development-ciieid

Miranda, Deborah. 2010. Extermination of the Joyas. Gendercide in Spanish California. GLQ, A Journal of Lesbian and Gay Studies 16(1-2): 253:284.

Mohanty, Chandra Talpade. 2013. Transnational feminist crossings: On neoliberalism and radical critique. Signs: Journal of Women in Culture and Society 38(4): 967-991.

Moreton-Robinson, Aileen. 2011. The White Man's Burden. Australian Feminist Studies 26(70): 413-431.

Native Women's Association of Canada. 2014. Press Conference - Native Women's Association of Canada Presents Petitions for a National Public Inquiry into Murdered and Missing Aboriginal Women. http://www.nwac.ca/2014/02/ press-conference-nwac-presents-petition-for-a-national-public-inquiry-into-mmaw/

Native Women's Association of Canada. 2015. Fact Sheet: Violence Against Aboriginal Women. n.p. http://www.nwac.ca/programs/violence-prevention-toolkit 
Oullette, Grace Josephine Mildred Wuttunee. 2012. The fourth world: An indigenous perspective on feminism and aboriginal women's activism. Halifax, N.S: Fernwood Pub. Co.

Pal, Leslie. 2011. Beyond Policy Analysis: Public Issue Management in Turbulent Times. Toronto: Nelson Education.

Quijano, Anibal and Michael Ennis. 2000. Coloniality of Power, Eurocentrism, and Latin America. Nepantla: Views from South 1.3: 533-580.

Razack, Sherene. 2011. Timely Deaths: Medicalizing the Deaths of Aboriginal People in Policy Custody. Law, Culture and the Humanities: 352-74 .

Rosbech, Malise. 2013. What is Patriarchy. http://www.newleftproject.org/index.php/site/ article_comments/what_is_patriarchy

Rostow, W.W. 1956. The Take-Off Into Self-Sustained Growth. The Economic Journal 66(261): 25-48. http://home.sandiego.edu/ jmwilliams/rostow1956econmodern.pdf

Sánchez Nestor, Martha. 2005. Mujeres Indigenas en Mexico; accion y pensamiento, construyendo otras mujeres en nosotras mismas. Feminismos Disidentes en America Latina y El Caribe: 41-53.

Sanchez-Ramirez, Georgina. 2011. Notes on the sexual rights of indigenous women in Chiapas. Women's Health Journal 17(2).

Simpson, Leanne. 2014. Not Murdered and Not Missing, \#itendshere, 5 March. http:// nationsrising.org/not-murdered-and-not-missing/

Smith, Andrea. 2005. Sexual Violence and American Indian Genocide. Cambridge: South End Press.

Sweetman, Caroline, ed. 1998. Violence against Women. Oxfam Focus on Gender. Oxford: Oxfam.

UN Women. n.d. CEDAW General Recommendations. http://www.un.org/ womenwatch/daw/cedaw/text/econvention.htm\#article1

Velasquez Nimatuj, Irma Alicia. 2012. Desafio Maya: “¿Objetos de studio” o sujetos intelectuales? Latin American Studies Association Forum Winter 43(I): 21-22.

Wingrove, Josh. 2014. Canada's new Prostitution Laws: Everything you Need to Know. The Globe and Mail, 15 July. http://www.theglobeandmail.com/news/politics/ canadas-new-prostitution-laws-everything-you-need-to-know/article19610318/ 